\title{
Swedish Trends in Criminal Assaults against Minors since Banning Spanking, 1981-2010
}

\author{
Robert E. Larzelere ${ }^{1^{*}}$, Taren Swindle ${ }^{2}$ and Byron R. Johnson ${ }^{3}$ \\ ${ }^{1}$ Oklahoma State University, USA \\ ${ }^{2}$ University of Arkansas for Medical Sciences, USA \\ ${ }^{3}$ Baylor University, USA
}

\begin{abstract}
This study uses Swedish trends in alleged criminal assaults against minors to investigate whether societal violence has decreased since their spanking ban in 1979. The rates of all assaults increased dramatically. Compared to 1981, criminal statistics in 2010 included about 22 times as many cases of physical child abuse, 24 times as many assaults by minors against minors, and 73 times as many rapes of minors under the age of 15 . Although the first cohort born after the spanking ban showed a smaller percentage increase in perpetrating assaults against minors than other age cohorts, those born since the spanking ban had almost a 12-fold increase in perpetrations altogether, compared to a 7 -fold increase for older age cohorts. Although some increases might reflect changes in reporting practices, their magnitude and consistency suggest that part of these increases are real. Recent increases may be due to expanding proscriptions against nonphysical disciplinary consequences. Future research needs to identify effective alternative disciplinary consequences to replace spanking. Otherwise, proscriptions against an expanding range of disciplinary consequences may undermine the kind of appropriate parental authority that can facilitate the development of impulse control in oppositional children and appropriate respect for others, especially the physically vulnerable.
\end{abstract}

Keywords: Criminal assaults, spanking bans, rapes, child abuse, Sweden.

\section{INTRODUCTION}

The Western world has experienced a long-term secular trend away from authoritarian parenting toward permissive parenting during the past 70 years (Forehand and McKinney 1993). Corporal punishment by parents has been banned in 33 countries, starting with Sweden in 1979 (Center for Effective Discipline 2012). Nonphysical disciplinary consequences are also falling into disfavor, sometimes explicitly as in New Zealand's ban of all use of disciplinary force (making it a crime to take a toddler to time-out against his will, at least technically: Bradford 2007), and sometimes implicitly with expanding proscriptions against all negative disciplinary consequences, such as grounding and privilege removal (Janson 2001; Patterson and Fisher 2002). If too many traditional disciplinary consequences fall into disfavor, it could undermine the type of firm control that is optimal when combined with nurturance in authoritative parenting (Baumrind, Larzelere, and Owens 2010; Larzelere, Morris, and Harrist 2013; Steinberg 2001). Some spanking-ban proponents suggest that spanking can be replaced with positive discipline only (e.g., Durrant 2011; Durrant 2007), whereas clinical cases indicate that some spanking bans have undermined the use of effective disciplinary consequences, such as time out (Patterson

*Address correspondence to this author at the Dept of Human Development and Family Science, 233 Human Sciences Bldg., Stillwater, OK 74078, USA; Tel: (405) 744-2053; E-mail: robert.larzelere@okstate.edu and Fisher 2002:74). Sweden was the first country to ban spanking as part of its permissive approach to parental discipline (Haeuser 1988), and support for other disciplinary consequences, such as withholding privileges, continues to erode in that country (Janson 2001). Sweden also maintains excellent criminal records which this study uses to test whether criminal assaults against minors have decreased since they banned spanking, as predicted by Straus (2001:212215), or whether they have increased since then.

The few evaluations of spanking bans to date have been contradictory. In 1999, for example, Larzelere and Johnson (1999) and Durrant (1999) published very different evaluations of the effects of the Swedish spanking ban even though they relied mostly on the same data source. Their debate focused on how to interpret statistics about child abuse and other criminal assaults and has continued in unpublished papers (Durrant 2000, March 15; Durrant 2005; Larzelere 2000, March 19; Larzelere 2004; Larzelere 2005). Durrant concluded that physical abuse was almost nonexistent in Sweden and that children raised since the spanking ban were less violent than previous generations. In contrast, Larzelere and Johnson (1999) found no evidence that child abuse had declined after Sweden's spanking ban and reported some evidence that it had increased almost six-fold, based on the same data source used by Durrant (1999) for other assault statistics (Wittrock 1995). A study by two Swedish psychiatrists corroborated a four-fold increase 
in physical child abuse against Swedish children under the age of 15 from 1986 to 1995 (Lindell and Svedin 2001). Durrant (1999) and Larzelere and Johnson (1999) agreed that Swedish deaths due to child abuse were so low before their spanking ban that a further decrease was impossible.

Durrant's (1999) evidence that children who grew up after the spanking ban were less violent than older age cohorts was questioned by Larzelere (2004), who showed that her least-violent group consisted of those who were 10 to 14 years old when the ban was passed in 1979 (see Table 1). Percentagewise, that age cohort increased their violence against minors less than any other age cohort, but younger cohorts had the largest percentage increases in assaults against minors through 1994, especially those born after the spanking ban. For example, assaults by minors against minors had increased six-fold from 1981 through 1994 (see Figure 1).

Durrant (2005) argued that these apparent increases in assaults by minors against minors and in physical abuse of young children reflected the fact that more minor offenses were being reported as Sweden became less tolerant of all violence, a widely acknowledged possibility (Larzelere and Johnson 1999; Lindell and Svedin 2001; Nilsson, Horgby, and Borres 2001; Wittrock 1995). Nonetheless, countries considering similar bans need to know whether a substantial portion of these increases reflect actual increases or whether the entire increase can be accounted for by other factors, such as increases in reporting mild assaults that would not have been reported to police previously. Several studies have attempted to distinguish these possibilities. Durrant (1999:439) said that it would be more appropriate to focus on the subset of child abuse cases that were aggravated assaults, but these were found to increase at least as fast as milder allegations from 1984 to 1994 (Larzelere 2004; Larzelere 2005). A Swedish study reported that the percentage of reported child abuse cases that involved "serious physical injuries" fell from $13 \%$ to $10 \%$ from 1990 to 1997 (Nilsson 2000). Yet its data showed that serious injuries increased $65 \%$ during those years, because the total number of reported child abuse cases increased from 330 to 709 , resulting in an increase from 43 cases $(0.13 \times 330=43)$ to 71 cases of serious physical injuries $(0.10 \times 709=71)$.

As for assaults by minors against minors, Durrant suggested that the large increases in those raised after the 1979 spanking ban were due to police involvement in anti-bullying interventions in schools (Durrant 2005). This possibility was also suggested by von Hofer (von Hofer 1995), but we know of no studies corroborating this explanation. This explanation would be more convincing if the timing of the introduction or expansion of anti-bullying interventions were shown to correspond with a sharp increase in criminal assault statistics. Instead, the trend in juvenile criminal assaults shows a steady accelerating increase in assaults by minors against minors through 1994. At some point, however, anti-bullying efforts should start reducing the number of criminal assaults in schools, which should be reflected in the subsequent trends through 2010 used in this study.

Some Swedish authorities considered it plausible that part of these increases were real in the mid-1990s. At least two studies were initiated then because of societal concerns about increasing youth violence. The rationale for one study was that "There is also much evidence that our [Swedish] society has a growing propensity for violence" (Statistics Sweden 1996:5). Another study's rationale began,

Table 1: Alleged Criminal Assaults Against 7- to 14-Year-Olds in Sweden by Age of Perpetrator

\begin{tabular}{|c|c|c|c|c|c|c|c|c|c|}
\hline \multirow[b]{2}{*}{$\begin{array}{l}\text { Age of } \\
\text { Suspect }\end{array}$} & \multicolumn{2}{|c|}{1984} & \multicolumn{3}{|c|}{1994} & \multicolumn{4}{|c|}{2010} \\
\hline & $\begin{array}{l}\text { Number of } \\
\text { Suspects }\end{array}$ & Birth Year & $\begin{array}{l}\text { Number of } \\
\text { Suspects }\end{array}$ & Birth Year & $\begin{array}{c}\text { Percent } \\
\text { Increase } \\
\text { since } 1984\end{array}$ & $\begin{array}{l}\text { Number of } \\
\text { Suspects }\end{array}$ & Birth Year & $\begin{array}{c}\text { Percent } \\
\text { Increase } \\
\text { since } 1984\end{array}$ & $\begin{array}{l}\text { Percent Increase } \\
\text { since } 1994\end{array}$ \\
\hline$<15$ & 116 & $1970+$ & 718 & $1980+$ & $519 \%$ & 2194 & $1996+$ & $1791 \%$ & $206 \%$ \\
\hline $15-19$ & 107 & $1965-69$ & 354 & $1975-79$ & 231 & 677 & 1991-95 & 533 & 91 \\
\hline $20-24$ & 12 & $1960-64$ & 28 & $1970-74$ & 133 & 42 & $1986-90$ & 250 & 50 \\
\hline $25-29$ & 19 & 1955-59 & 29 & 1965-69 & 53 & 92 & 1981-85 & 384 & 217 \\
\hline $30-39$ & 68 & $1945-54$ & 151 & $1955-64$ & 122 & 428 & $1971-80$ & 529 & 183 \\
\hline $40-49$ & 47 & $1935-44$ & 116 & $1945-54$ & 147 & 436 & 1961-70 & 828 & 276 \\
\hline $50+$ & 25 & $<1935$ & 57 & $<1945$ & 128 & 183 & $<1961$ & 632 & 221 \\
\hline
\end{tabular}

Note: Age cohorts born after the 1979 spanking ban are indicated in bold. This table reports percentage increases since 1984 to be consistent with earlier analyses (Durrant 2005; Larzelere 2004; Larzelere 2005; Wittrock 1995). 
Since the mid-1980s, the Swedish public has been increasingly concerned about juvenile violence [including] football hooliganism, excessive celebrations on Midsummer eve, acts of violence with racist and xenophobic motives, squatters' actions, street fights between politically opposed groups, violence at school, and recurrent juvenile tumults at the end of summer vacations, between gangs of Swedish or immigrant background, and skinheads and groups of young female 'kickers' ... In light of this, it seems difficult to deny that the Swedish society in recent years has been hit by a wave of juvenile violence. (von Hofer 1995:1)

Juvenile violence clearly appeared to be increasing during the 1990s according to these Swedish social scientists, warranting these studies to investigate the problem. After looking at various trends, von Hofer said that it was inconclusive whether recent trends in juvenile violence (i.e., 16-20-year-olds) were actually increasing or were merely being enforced more often. His final sentence stated, "No doubt, there is reason to look deeper into the matter" (von Hofer 1995:12). However, his victimization surveys showed that street violence requiring medical care in 16- to 20-year-olds increased by $130 \%$ from 1982 to 1993, whereas milder types of street violence reported by victims of those ages decreased by $10 \%$ (his Chart 8 ). He also corroborated the fact that criminal assaults by younger adolescents showed the steepest increase in alleged assaults against minors from 1975 to 1994 .

In addition to updated Swedish trends in criminal assaults through 2010 , this study uses rape statistics between 1981 and 2010 to test the possibility that increasing trends in criminal assaults are due to antibullying interventions or increased reporting of minor assaults. If anti-bullying programs account for the increases in criminal assaults by minors against minors in schools, then the increases in rape statistics should be much less, because rapes rarely occur in schools. In contrast, if the criminal-assault trends are due to an actual increase in societal violence, that increase should be reflected in both private assaults such as rapes and in public assaults in schools.

The fact that Swedish rape statistics distinguish attempted from completed rapes also provides a test for the changing-threshold explanation in the following way: If the increases in reported assaults are occurring only because minor assaults are more likely to be reported to police, then attempted rapes should be increasing more than completed rapes. On the other hand, if the increases are occurring for severe violence, those increases should be shown in completed rapes as well as in attempted rapes.

This study will also test Durrant's ingenious cohortcomparison hypothesis: If spanking bans reduce

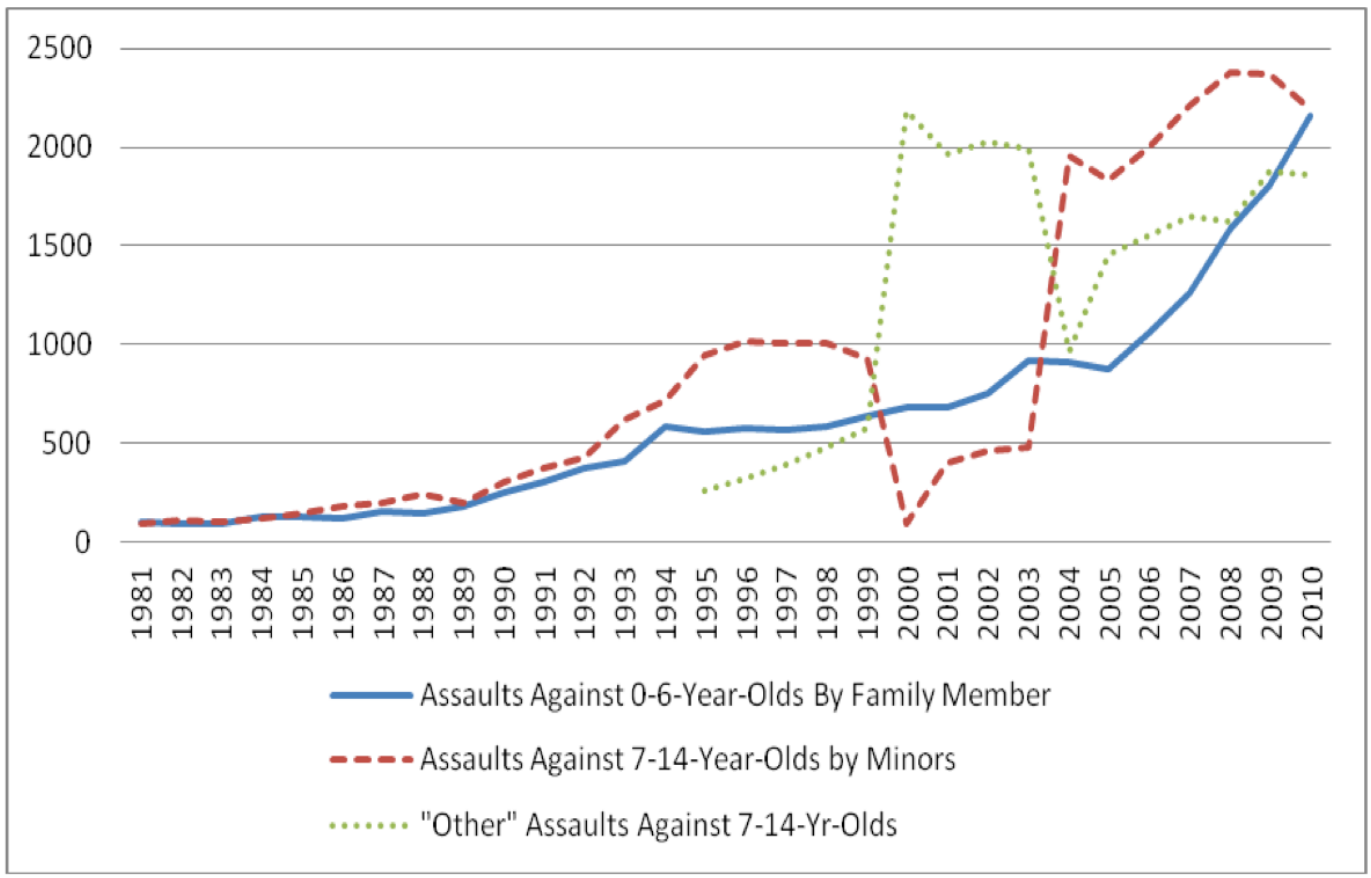

Figure 1: Reported criminal assaults against children in Sweden, 1981-2010. 
violence in society, it should be reflected in the age distribution of perpetrators of criminal violence. Those raised after the spanking ban should represent a decreasing proportion of perpetrators of violence.

This study therefore tests five trends from Swedish criminal assault statistics from 1981 through 2010 as distinct indicators of the overall hypothesis that spanking bans will eventually reduce criminally violent acts in Sweden. The first two tests are that physical child abuse rates and rates of assaults by minors against minors should both start decreasing, despite their initial increases reported previously. Third, the decrease in criminal assaults should be more pronounced in perpetrators born after the spanking ban than in older age cohorts who grew up before the ban. Fourth, rape statistics should not increase as much as other assaults, because they would not be inflated by anti-bullying interventions in schools. Fifth, rape attempts should be increasing more than completed rapes if increases in assaults are due to increasingly minor assaults being reported to police.

If criminal assaults are decreasing or can be explained by changes in reporting, this would support the view that other countries should emulate Swedish examples in parenting policies and recommendations. If, on the other hand, criminal assaults are increasing in ways not accountable by reporting artifacts, then it would suggest that spanking bans need to be reconsidered or to be implemented in more effective ways that do not undermine appropriate parental authority.

\section{METHODS}

We obtained criminal assault data from the Official Swedish Crime Statistics published by their National Council for Crime Prevention (2011). These data have been used previously in Swedish reports to summarize trends in assaults against children (Wittrock 1995) and were used previously by both Durrant (1999) and Larzelere and Johnson (1999). The child abuse data are alleged criminal assaults against children under 7 years old committed indoors by someone known to the child. The data on alleged criminal assaults against minors are based on victims between ages 7 and 14 . Annual tables categorize these assaults by age of the alleged perpetrator. Alleged rape statistics are divided into attempted and completed rapes and into victims who were under 15 years or older than that.

The shortcomings of official crime statistics are well known. Criminologists have written at length about the "dark side" of crime that are not reported to police, which is especially problematic for rape statistics. That said, official crime statistics remain the most widely accepted objective measure of crime and thus served as the data to test this study's hypotheses.

\section{RESULTS}

The results of the first two specific hypotheses are shown in Figure 1, which presents the total number of alleged cases of physical child abuse and of assaults by minors against minors from 1981 through 2010 . According to the first of these criminal statistics, physical child abuse continued to increase since 1994 albeit at a slower rate from 1994 through 2005. The number of child abuse allegations then increased more steeply from 2005-2010. The number of alleged cases in 2010 was 21.8 times more than in 1981 (2157 compared to 99 ).

Second, criminal assaults by minors against 7 - to 14-year-olds also continued to increase, until such allegations in 2010 occurred 23.6 times more often than in 1981 (2194 vs. 93 assaults). The temporary decrease from 2000 to 2003 was apparently due to many assaults being categorized in two "Other" categories rather than in the "minor-aged perpetrator" category during those years ( $A$. Lennero, personal communication, May 6, 2009). Accordingly, Figure 1 shows that the decreased rates from 2000 to 2003 were balanced by increased rates in "Other" cases.

Third, children who were born during the first decade after 1979 constituted a smaller percentage increase in perpetrating criminal assaults against minors than any other age cohort of perpetrators, partially supporting Durrant's age-distribution hypothesis (see Table 1). By 2010, they were 20 to 29 years old, an age group that had a $332 \%$ increase in assault perpetrations since 1984, the starting year in previous analyses of these trends (Durrant 1999; Larzelere and Johnson 1999; Wittrock 1995). Although this increase was more than 4-fold, it was a slower rate of increase than any other age cohort. On the other hand, criminal assaults by minors against minors occurred almost 19 times as often in 2010 as in 1984 (a $1791 \%$ increase), and perpetration rates by older teenagers (15 to 19 years old) increased more than 6fold during that period (a $533 \%$ increase). Combining all cohorts, those born since the spanking ban increased their perpetration rates faster than older cohorts. Those born in 1981 or later increased their perpetrated assaults by $1083 \%$, almost a 12 -fold 


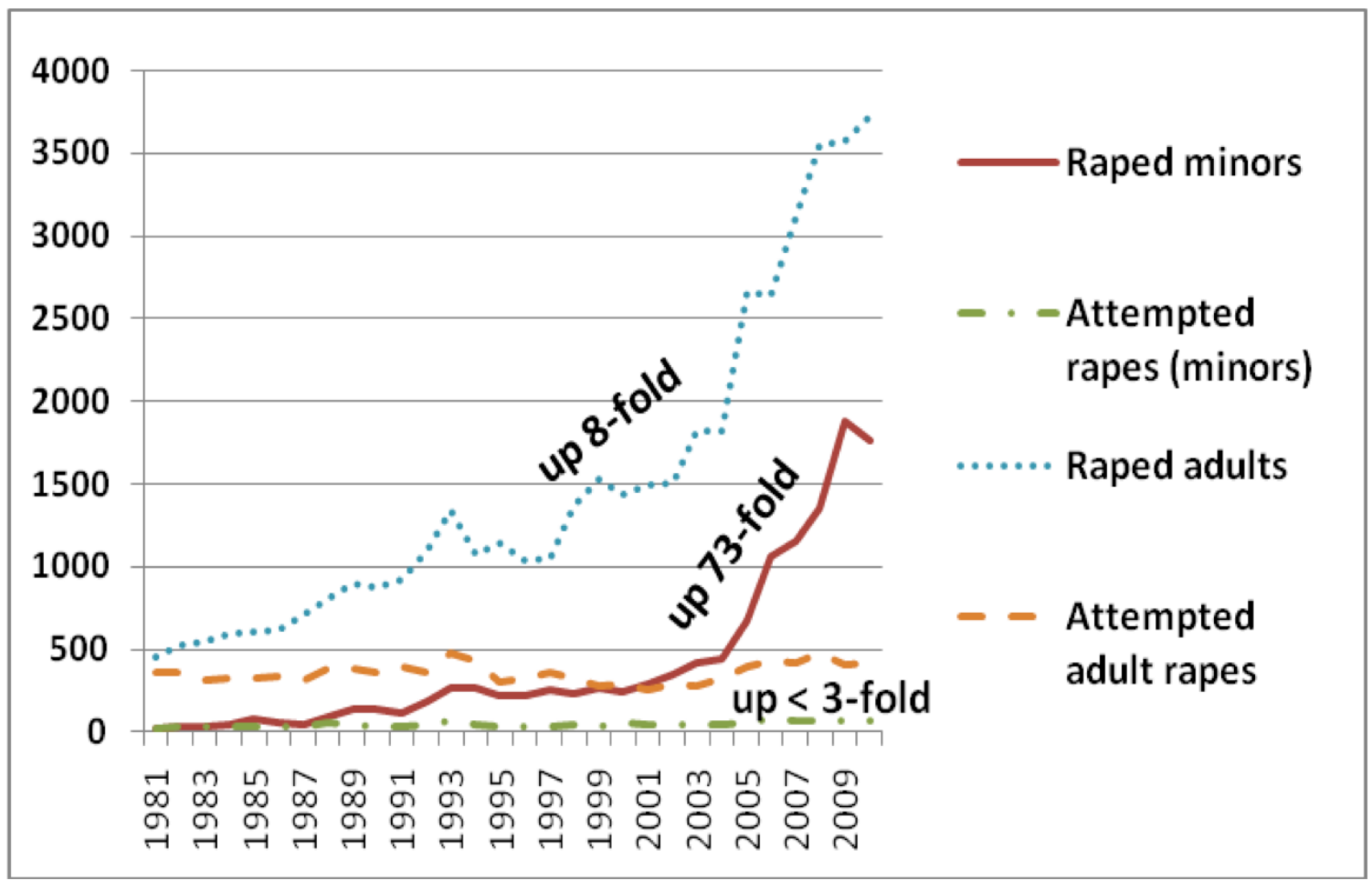

Figure 2: Number of reported rapes in Sweden by type and victim's age, 1981-2010 (In Sweden, minors are children under the age of 15).

increase $(100 \%+1083 \%$ increase $=1183 \%$ of the original). By comparison, those born before the spanking ban increased their perpetrated assaults "only" $648 \%$, more than a 7 -fold increase $(100 \%+$ $648 \%=748 \%$ ). Thus those born after the spanking ban increased their portion of the age distribution of assault perpetrators by almost twice as much as those born after the spanking ban.

Fourth, rapes of children under the age of 15 occurred over 73 times as often in 2010 as in 1981 (1762 rapes compared to 24). To compare with previously reported time periods, rapes against minors increased more than six-fold from 1984 through 1994 (40 to 264), a rate of increase about the same as the increase in assaults by minors against minors (Table 1). Since 1994, rapes of minors increased $567 \%$ through 2010, more than double the percentage increase in general assaults by minors against minors during that period.

Finally, completed rapes of minors increased far more than attempted rapes. Whereas rapes of children under the age of 15 increased 73 times from 1981 to 2010, attempted rapes of minors increased less than 3fold, from 24 to 68 attempted rapes. Rapes of adults older than 14 also increased much more than rape attempts, an increase over 8 times for rapes (451 to
3721) compared to a $12 \%$ increase in reported attempts (366 to 413 ).

\section{DISCUSSION}

Together, these five trends in Swedish criminal assaults against minors suggest that the way the first spanking ban has been implemented in that country may have increased criminal assaults in that country, in contrast to its intended effect of decreasing violence. The one exception was that those born in the first decade after Sweden's spanking ban increased their rate of perpetrating assaults against minors at a slower rate than other age cohorts, now that they were in their twenties. Whereas they had exhibited a 6 -fold increase in assaults against minors from 1984 to 1994 (the $519 \%$ increase for those under 15 in Table 1), they exhibited a 4-fold increase through 2010, comparing 20- to 29-year-old perpetrators in 1984 to 20- to 29year-olds in 2010. Although this was still a substantial increase, it was a smaller percentage increase than for any other age cohort. However, the combination of all age cohorts born after the spanking ban was increasing its rate of perpetrating violence against minors almost twice as much as older age cohorts.

All the other results indicated that assaults against minors continued their substantial increases in Sweden 
in an overall pattern that is difficult to explain by reporting artifacts alone. The number of assaults by minors against minors continued increasing into the $21^{\text {st }}$ century, now being reported more than 23 times as often in 2010 as in 1981. If the increase were due to anti-bullying efforts, the trend should have reached a plateau or started to decrease. The fact that completed rapes of minors have increased as much or more is further evidence against accounting for these increases by anti-bullying programs alone, which would primarily inflate reports of public assaults in schools.

As stated earlier, a major motivation for spanking bans was to reduce physical child abuse. Therefore, the large 22-fold increase in the number of physical child abuse allegations should be a concern for all interested in reducing child abuse. We know of only one study that has found reduced rates of severe physical violence following a spanking ban, which occurred in Germany at a time when fewer than $30 \%$ of parents were aware that spanking had been banned (Bussmann 2004).

Although a portion of these increases could reflect changes in reporting (Durrant 1999; Larzelere and Johnson 1999; Wittrock 1995), we know of no convincing evidence that the entire increase is due to reporting increasingly mild assaults. The large increase in completed rapes against the most vulnerable victims is further evidence that the increase in societal violence in Sweden is real, accounting at least for part of that 73-fold increase. The fact that reported rapes increased far more than rape attempts is evidence that these increases in assaults cannot be explained only by an increase in reporting minor offences.

Despite the best of intentions, proscriptions against negative disciplinary consequences may inadvertently undermine appropriate parental discipline. If so, a small, but increasing percentage of boys may grow up with a dangerous combination of disrespect for their mothers and a lack of impulse control. Without appropriate parental discipline, such boys learn to get whatever they want when they want it regardless of their mothers' disapproval (Patterson and Fisher 2002). For some boys, this disregard for others' disapproval may generalize to other females, who are then at risk of becoming their rape victims. We are not claiming that this is the only possible explanation of the increase in rapes of minors, but it is a plausible explanation for part of the increase. It seems unlikely that Swedish children were 73 times more likely to press charges after completed rapes in 2010 than in 1981. For this explanation to account for the entire trend, the increase in probability of reporting rapes would have to be greater for completed rapes than for attempted rapes and for younger victims than for victims over 14 years of age. It seems difficult to believe that increased probabilities of pressing charges could account for this large of an increase in reported rapes of minors.

The spanking ban itself could only plausibly influence the increases in these three criminal assault statistics through the mid-1990s. The continued increase in these assaults since then would have to be explained by more recent changes. One possibility is that the long-term trend away from authoritarian parenting is continuing, eroding support for appropriate types of negative disciplinary consequences. Alternatives such as grounding and removing allowances have fallen into disfavor in Sweden (Janson 2001). Only $31 \%$ of $10-12$-year-olds in Sweden thought parents had the right to ground them in 2000, a drop from $43 \%$ of 13 - to 15 -year-olds in 1994-95. The perceived right for parents to threaten to forbid something decreased from almost $39 \%$ to under $4 \%$ in the same study (Janson 2001:58). Clinical cases have indicated that children's antisocial behavior in neighboring Norway is now more associated with an extreme form of permissive parenting than with authoritarian parenting, according to professionals personally opposed to spanking (Patterson and Fisher 2002). This erosion of support for nonphysical disciplinary consequences may account partly for the increases in all three types of criminal assaults in Sweden from 1994 to 2010.

Of course, any causal conclusions must be made tentatively. Other factors were undoubtedly responsible for part of these increases, such as the increased availability of violent films and video games in Scandinavia. Nonetheless, rigorous evaluations of spanking bans are sorely needed, as we concluded 14 years ago (Larzelere and Johnson 1999). Before emulating Sweden's parenting policies, other countries need a convincing explanation of their increases in criminal assaults against minors, so that they can try to avoid such increased violence themselves.

\section{CONCLUSIONS}

Spanking bans continue to be adopted despite the lack of objective evidence of their success. Their success may depend upon parents learning effective alternatives to use in disciplinary situations in which spanking had been an option traditionally. Neither 
supporters (Gershoff, Grogan-Kaylor, Lansford, Chang, Zelli, Deater-Deckard, and Dodge 2010; Van Leeuwen, Fauchier, and Straus 2012) nor critics of spanking bans (Larzelere, Cox, and Smith 2010; Larzelere and Kuhn 2005) have been able to identify alternative disciplinary tactics that are effective in reducing child behavior problems in naturally occurring data. Indeed, a brief and forceful room isolation is the only enforcement for time out that has proven to be as effective as the traditional spank enforcement for clinically defiant 2- to 6 -year-olds in direct comparisons (Larzelere and Kuhn 2005; Roberts and Powers 1990). It is therefore the preferred enforcement for time out in two of the bestsupported parent training programs for young children (McNeil and Hembree-Kigin 2010; Webster-Stratton 1992). Yet it is prohibited explicitly in New Zealand (Bradford 2007) and implicitly in Sweden and Norway (Patterson and Fisher 2002).

Opposition to effective alternatives to replace spanking, such as time out and its enforcements, may have undermined appropriate parental discipline in these Scandinavian countries. At least one leading expert thinks so. Marion Forgatch supervised a nationwide training of Norwegian parenting educators to implement the Parent Management Training Oregon Model, the best supported clinical treatment for young children with disruptive disorders (Eyberg, Nelson, and Boggs 2008). Although personally opposed to spanking, she told the first co-author that a possible iatrogenic effect of Norway's spanking ban was not "so much the ban on spanking per se, but disempowerment of parents and [the] mistaken notion that they can't set any negative sanctions for problematic behavior" (M. Forgatch, personal communication, April 18, 2007). This suggests that spanking bans may undermine appropriate parental discipline if spanking is not replaced with alternative disciplinary tactics that are effective for defiant children as well as easily managed children.

Some have wondered how spanking bans could have such a large effect. One possibility is that more forceful disciplinary tactics are necessary to enforce cooperation with milder disciplinary tactics, especially for temperamentally difficult children. Studies by Roberts (Bean and Roberts 1981; Roberts and Powers 1990) showed that that a forceful back-up was necessary for most clinically defiant 2- to 6-year-olds to cooperate with time out, which in turn was essential for the effectiveness of behavioral parent training. Similarly, Larzelere et al. (1998) showed that disciplinary reasoning was effective with 2- and 3-year- olds only when it was enforced with nonphysical punishment at least 10 percent of the time (time out or privilege removal). Thus more forceful disciplinary tactics are sometimes necessary to get adequate cooperation with milder tactics (Larzelere, Cox, and Mandara 2013). If too many forceful tactics are outlawed or discouraged, milder disciplinary tactics may become ineffective, especially with temperamentally difficult children, who are most likely to become perpetrators of criminal assaults when they get older.

Larzelere and Johnson (1999) speculated that the decreased support for mild spanking (Statistics Sweden 1996) may have increased the risk for escalating parental frustration in difficult disciplinary episodes, thereby accounting for the apparent increase in physical child abuse by 1994. The decreasing approval of alternative nonphysical consequences may have further exacerbated parental frustration when oppositional children are defiant. These issues need to be addressed objectively for spanking bans to achieve their desired goal of reducing societal violence. Social scientists need more discriminating scientific evidence about spanking and alternative disciplinary consequences to provide sound disciplinary recommendations to parents and to provide informed input on related policies and laws (Larzelere and Baumrind 2010; Larzelere and Kuhn 2005). Otherwise, Western societies may inadvertently be undermining appropriate parental authority in their well-intentioned efforts to oppose authoritarian parenting and child abuse.

\section{REFERENCES}

Baumrind, Diana, Robert E. Larzelere, and Elizabeth B. Owens. 2010. "Effects of preschool parents' power assertive patterns and practices on adolescent development." Parenting: Science and Practice 10: 157-201. http://dx.doi.org/10.1080/15295190903290790

Bean, Arthur W. and Mark W. Roberts. 1981. "The Effect of Time-out Release Contingencies on Changes in Child Noncompliance." Journal of Abnormal Child Psychology 9: 95-105. http://dx.doi.org/10.1007/BF00917860

Bradford, Sue. 2007. "Crimes (Substituted Section 59) Amendment Bill." Wellington, New Zealand: House of Representatives.

Bussmann, Kai-D. 2004. "Evaluating the Subtle Impact of a Ban on Corporal Punishment of Children in Germany." Child Abuse Review 13: 292-311. http://dx.doi.org/10.1002/car.866

Center for Effective Discipline. 2012. Discipline and the law: Retrieved August 6, 2012 from http: //www.stophitting.com/index.php?page=laws-main.

Durrant, Joan (Moderator). 2011. "Encouraging Positive Discipline in Homes Worldwide. Paper session at the conference on 
Global Summit on Ending Corporal Punishment and Promoting Positive Discipline, June 3, Dallas, TX.

Durrant, Joan E. 1999. "Evaluating the Success of Sweden's Corporal Punishment Ban." Child Abuse \& Neglect 5: 435448.

http://dx.doi.org/10.1016/S0145-2134(99)00021-6

Durrant, Joan E. 2000, March 15. "Child Abuse in Sweden." in Child Maltreatment Research Listserv. Cornell University.

Durrant, Joan E. 2005. Law Reform and Corporal Punishment in Sweden: Response to Robert Larzelere, The Christian Institute, and Families First. Winnepeg: Department of Family Social Sciences, University of Manitoba (http: //www.umanitoba.ca/faculties/human_ecology/media/Durrant 2.pdf).

Durrant, Joan E. 2007. Positive Discipline: What it is and How to Do it. Bangkok, Thailand: Save the Children Sweden.

Eyberg, Sheila M., Melanie M. Nelson, and Stephen R. Boggs. 2008. "Evidence-based Psychosocial Treatments for Children and Adolescents with Disruptive Behavior." Journal of Clinical Child and Adolescent Psychology 37: 215-237. http://dx.doi.org/10.1080/15374410701820117

Forehand, Rex and B. McKinney. 1993. "Historical Overview of Child Discipline in the United States: Implications for Mental Health Clinicians and Researchers." Journal of Child \& Family Studies 2: 221-228. http://dx.doi.org/10.1007/BF01321332

Gershoff, Elizabeth T., Andrew Grogan-Kaylor, Jennifer E. Lansford, Lei Chang, Arnaldo Zelli, Kirby Deater-Deckard, and Kenneth A. Dodge. 2010. "Parent Discipline Practices in an International Sample: Associations with Child Behaviors and Moderation by Perceived Normativeness." Child Development 81: 487-502. http://dx.doi.org/10.1111/j.1467-8624.2009.01409.x

Haeuser, Adrienne Ahlgren. 1988. Reducing Violence Towards U.S. Children: Transferring Positive Innovations from Sweden: Unpublished manuscript. (Available from author, School of Social Welfare, University of Wisconsin-Milwaukee, 53201).

Janson, Staffan. 2001. Barn och Misshandel: En Rapport om Kroppslig Bestraffning och Annan Misshandel i Sverige vid Slutet av 1900-Talet [Children and Physical Abuse: A Report about Corporal Punishment and Other Physical Abuse in Sweden at the End of the 20th Century] (SOU 2001: 18). Stockholm: Statens Offentliga Utredningar.

Larzelere, Robert E., Ronald B. Cox, Jr., and Jelani Mandara. 2013. "Responding to Misbehavior in Young Children: How Authoritative Parents Enhance Reasoning with Firm Control." Pp. 89-111 in Authoritative parenting: Synthesizing nurturance and discipline for optimal child development, edited by R. E. Larzelere, A. M. Morris, and A. W. Harrist. Washington, DC: American Psychological Association.

Larzelere, Robert E., Paul R. Sather, William N. Schneider, David B. Larson, and Patricia L. Pike. 1998. "Punishment Enhances Reasoning's Effectiveness as a Disciplinary Response to Toddlers." Journal of Marriage and the Family 60: 388-403. http://dx.doi.org/10.2307/353856

Larzelere, Robert E. 2000, March 19. "Child Abuse in Sweden." in Child Maltreatment Research Listserv. Cornell University elist server.

Larzelere, Robert E. 2004. Sweden's Smacking Ban: More Harm than Good. Frinton on Sea, Essex, UK: Families First.

Larzelere, Robert E. 2005. "Differentiating Evidence from Advocacy in Evaluating Sweden's Spanking Ban: A Response to Joan Durrant's Critique of my Booklet "Sweden's Smacking Ban: More Harm than Good"." Stillwater, OK: Oklahoma State University (http://humansciences.okstate.edu/facultystaff/ Larzelere/rdurrunl.75.pdf).

Larzelere, Robert E. and Diana Baumrind. 2010. "Are Spanking Injunctions Scientifically Supported?" Law and Contemporary Problems 73: 57-88.
Larzelere, Robert E., Ronald B. Cox, Jr., and Gail L. Smith. 2010. "Do Nonphysical Punishments Reduce Antisocial Behavior More Than Spanking? A Comparison Using the Strongest Previous Causal Evidence Against Spanking." BMC Pediatrics 10. http://dx.doi.org/10.1186/1471-2431-10-10

Larzelere, Robert E. and Byron Johnson. 1999. "Evaluation of the Effects of Sweden's Spanking Ban on Physical Child Abuse Rates: A Literature Review." Psychological Reports 85: 381392.

Larzelere, Robert E. and Brett R. Kuhn. 2005. "Comparing Child Outcomes of Physical Punishment and Alternative Disciplinary Tactics: A Meta-analysis." Clinical Child and Family Psychology Review 8: 1-37. http://dx.doi.org/10.1007/s10567-005-2340-z

Larzelere, Robert E., Amanda Sheffield Morris, and Amanda W. Harrist. 2013. Authoritative Parenting: Synthesizing Nurturance and Discipline for Optimal Child Development. Washington, DC: American Psychological Association Press. http://dx.doi.org/10.1037/13948-000

Lindell, C. and C. G. Svedin. 2001. "Physical Child Abuse in Sweden: A Study of Police Reports between 1986 and 1996." Social Psychiatry and Psychiatric Epidemiology 36: 150-157. http://dx.doi.org/10.1007/s001270050304

McNeil, Cheryl B. and Toni L. Hembree-Kigin. 2010. Parent-Child Interaction Therapy. New York: Springer. http://dx.doi.org/10.1007/978-0-387-88639-8

National Council for Crime Prevention. 2011. "Annual Summary Tables 100, 170, and 200 for 1981-2010." in Official Swedish Crime Statistics.

Nilsson, Christian, Kerstin Horgby, and Magnus P. Borres. 2001. "Barnmisshandel Okar Stadigt i Sverige -- Stammer det med Verkligheten? [Increasing number of police reports on child assault - in accordance with reality?]." Lakartidningen 98: 2298-2301.

Nilsson, Lotta. 2000. "Barnmisshandel: En Kartlaggning av Polisanmald Misshandel av sma Barn." National Council for Crime Prevention, Stockholm.

Patterson, Gerald R. and Philip A. Fisher. 2002. "Recent Developments in our Understanding of Parenting: Bidirectional Effects, Causal Models, and the Search for Parsimony." Pp. 59-88 in Handbook of Parenting: Vol. 5. Practical Issues in Parenting, edited by M. H. Bornstein. Mahwah, NJ: Erlbaum.

Roberts, Mark W. and Scott W. Powers. 1990. "Adjusting Chair Timeout Enforcement Procedures for Oppositional Children." Behavior Therapy 21: 257-271. http://dx.doi.org/10.1016/S0005-7894(05)80329-6

Statistics Sweden. 1996. "Spanking and Other Forms of Physical Punishment." Author, Stockholm.

Steinberg, Laurence. 2001. "We Know Some Things: ParentAdolescent Relationships in Retrospect and Prospect." Journal of Research on Adolescence 11: 1-19. http://dx.doi.org/10.1111/1532-7795.00001

Straus, Murray A. 2001. Beating the Devil Out of Them: Corporal Punishment in American Families and its Effects on Children. New Brunswick, NJ: Transaction.

Van Leeuwen, Karla G., Angele Fauchier, and Murray A. Straus. 2012. "Assessing Dimensions of Parental Discipline." Journal of Psychopathology and Behavioral Assessment 34: 216231. http://dx.doi.org/10.1007/s10862-012-9278-5

von Hofer, Hanns. 1995. "Criminal Violence and Youth in Sweden in a Long-Term Perspective." Paper presented at the Xth International Workshop for Juvenile Criminology "Society, Violence and Youth". Siena, Italy. 
Webster-Stratton, C. 1992. The Incredible Years. Toronto, Ontario: Umbrella Press.
Wittrock, Ulla. 1995. "Barnmisshandel, 1984-1994 [Violent Crimes against Children, 1984-1994]." Pp. 5: 1-6 in KR Info: Stockholm: SCB [Central Office for Vital Statistics].

Received on 08-03-2013

Accepted on 16-04-2013

Published on 25-04-2013

DOI: http://dx.doi.org/10.6000/1929-4409.2013.02.13

(C) 2013 Larzelere et al.; Licensee Lifescience Global.

This is an open access article licensed under the terms of the Creative Commons Attribution Non-Commercial License (http://creativecommons.org/licenses/by-nc/3.0/) which permits unrestricted, non-commercial use, distribution and reproduction in any medium, provided the work is properly cited. 